\title{
A Comparative Anthelmentic Studies on Jasminum Grandiflorum and Cordia Diachotoma
}

\author{
Muskan M. Bhaldar*, Sandeep R. Kane, Hanmant S. Mali, Hemant S. Kandle \\ Department of Pharmaceutical Chemistry, Rajarambapu College of Pharmacy, Kasegaon, Maharashtra, India \\ *Corresponding Author : muskanbhaldar97@gmail.com
}

\begin{abstract}
Article Info

Volume 8, Issue 4

Page Number : 637-645

Publication Issue

July-August-2021

\section{Article History}

Accepted : 12 Aug 2021

Published : 22 Aug 2021

Anthelmintics are a class of antiparasitic drugs that eliminate parasitic worms (helminths) and other internal parasites from the body by stunning or destroying them without harming the host. They're also known as vermifuges (stun drugs) or vermicides (drugs that destroy vermin) (those that kill). Anthelmintics, a disease called helminthiasis, are used to treat individuals that are infected by helminths. For the care of infected animals, these medications are sometimes used. The extraction from leaves of Jasminum Grandiflorum and Cordia Dichotoma was done by soxhlet apparatus for 3 days by using alcohol (Ethanol) as solvent. After that the evaporation of solvent was done for obtaining solid form of extract. Phytochemical screening of solid form of extract was performed to study its contents ( Eg. Tannins, Alkaloids, Anthocynin, steroids, etc.)Cordia Dichotoma and Jasminum Grandiflorum extracts in ethanol were taken for anthelmintic activity against Parthitima Postuma which is an Indian earthworm. Various quantities of both extract were monitored and the results were expressed for paralysis and bacterial death time. Distilled water used as acontrol group. Dependent Activity of the dose of both plants was observed But Jasminum grandiflorum shows more activity than Cordia diachotoma .It was concluded that Both the studied plants had some anthelmintic activity, therefore, in vivo trials may be conducted for further.

Keywords : Jasminum Grandiflorum, Cordia Dichotoma, Anthelminthic Activity, Molecular Docking.
\end{abstract}

\section{INTRODUCTION}

Anthelmintics are a group of antiparasitic medicines that work locally to extract worms from the gastrointestinal tract or to eliminate adult helminths or types of growth systematically without causing significant host harm ${ }^{1}$. Natural anthelmintic agents can play an important role in the treatment of parasitic infections. Jasminum grandiflorum has been reported to have beneficial effects such as odontalgic, thermogenic, aphrodisiac, antiseptic, emollient, anthelmintic, deobstructive, suppurative, tonic, 
stomatitis, leprosy, skin diseases, otorea, otalgia, wounds, calluses, and aromatherapy in fixing loose teeth $^{2}$. Our careful literature search revealed an interesting fact that although the plant is a popular remedy for a variety of disorders; very little effort has been made to verify its effectiveness through scientific screening on animal models and clinical studies $^{3}$. The present study illustrates the numerous common, phytochemical and pharmacological uses of J. Grandiflorum and stresses its unexplored ability as well ${ }^{4}$. Cordia diachotoma his having the fruit contains saponins, amino acids, flavonoids, sugar, rubber, proteins, palmitic acid, stearic, linoleic, oleic, arachidic, behenic acid. Its fruits are used as cooling, astringent, diuretic, aphrodisiac, emollient, expectorant, anthelmintic and purgative ${ }^{5}$. The hazels were a good remedy in the dens. Analgesics, antiinflammatories and hepatoprotectives have also been reported by the plant. The current research was conducted to scientifically assess the anthelmintic behavior of Cordia dichotoma ${ }^{6}$.

The presence of phytochemicals such as steroids, terpenoids, carotenoids and flavanoids exhibiting antimicrobial, heamolytic and foaming activity was demonstrated by screening phytochemicals present in the leaf extracts of Jasminum grandiflorum and Cordia dichotoma 7 . Environmental factors can influence plant growth, such as soil conditions, temperature, altitude and precipitation, and in turn influence the production of phytochemicals in them ${ }^{8}$. The purpose of this research was to investigate the presence of phytochemical constituents in two different solvent extracts and the anthelmintic behavior of Jasminum grandiflorum and Cordia dichotoma ethanolic extract.

\section{METHODS AND MATERIAL}

\subsection{Collection and identification of plant and worms}

The test plant, Jasminum grandiflorum was collected from Modern Highschool, Sakhrale, Sangli, Maharashtra, India and Cordia dichotoma was collected from Yewalewadi Corner, Kasegaon, Sangli, Maharashtra . Dr. G. G. Potdar, Assistant Professer, Yashvantrao Chavan College of Science Karad, Maharashtra, India, authenticated this plant. Using an electric grinder, shade-dried leaf samples were cleaned, washed, dried and pulverized into coarse powder.

Pheretima posthuma (Indian earthworm) were collected from Rajarambapu Vermicompost Project, Rajaramnagar, Islampur, Sangli, Maharashtra, India and Dr..S U Patil. Head, Department Of Zoology, Smt. Kusumtai Rajarambapu Patil Kanya Mahavidyalaya, Islampur, Sangli, Maharashtra authenticated this earthworm.

\subsection{Extraction}

The dried leaf powder (20 g) of Jasmine grandiflorum leaf and Cordia diachotoma leaf was extracted separately by ethanol by keeping them in respective solvents for 48 hours with soxhlet apparatus and then evaporated to dryness and air dried at room temperature.

\subsection{Phytochemical Analysis}

The phytochemical constituents present in Jasminum grandiflorum leaf and Cordia dichotoma were carried out with solvent extracts as mentioned as follow using standard methods $\mathrm{s}^{9,10,11,12}$.

\begin{tabular}{|l|l|l|l|}
\hline Sr. No. & Phytochemical & Test & Positive Observation \\
\hline 1 & Alkaloids & $\begin{array}{l}1 \mathrm{ml} \text { of extract adds 1\% } \mathrm{HCl} \text { and } 6 \\
\text { drops of Mayer's reagent and few } \\
\text { drops of Dragendroff's reagent. }\end{array}$ & $\begin{array}{l}\text { Organic precipitate indicate } \\
\text { that presence of alkaloid }\end{array}$ \\
\hline 2 & Flavonoids & $\begin{array}{l}5 \mathrm{ml} \text { of dilute ammonia solution were } \\
\text { added to a portion of aqueous filtrate } \\
\text { of extract followed by addition of con. } \\
\mathrm{H}_{2} \mathrm{SO}_{4} .\end{array}$ & $\begin{array}{l}\text { A yellow coloration is } \\
\text { observed which confirms the } \\
\text { presence of flavonoids. }\end{array}$ \\
\hline
\end{tabular}




\begin{tabular}{|c|c|c|c|}
\hline 3 & Terpenoids & $\begin{array}{l}5 \mathrm{ml} \text { of extract was added to } 2 \mathrm{ml} \text { of } \\
\text { chloroform and } 3 \mathrm{ml} \text { of con. } \mathrm{H}_{2} \mathrm{SO}_{4} \text {. }\end{array}$ & $\begin{array}{l}\text { Formation of reddish brown } \\
\text { monolayer at coloration of the } \\
\text { interface was showed to form } \\
\text { positive result for terpenoids. }\end{array}$ \\
\hline 4 & Tannins & $\begin{array}{l}5 \mathrm{ml} \text { of extract was added to few drops } \\
\text { of } 1 \% \text { lead acetate. }\end{array}$ & $\begin{array}{l}\text { A yellow precipitate indicates } \\
\text { presence of tannin. }\end{array}$ \\
\hline 5 & Saponins & $\begin{array}{l}5 \mathrm{ml} \text { of extract was added to } 20 \mathrm{ml} \text { of } \\
\text { distilled water was agitated in a } \\
\text { graduated cylinder for } 15 \text { minutes. }\end{array}$ & $\begin{array}{l}\text { The formation of a layer of } \\
\text { foam indicates the presence of } \\
\text { saponins. }\end{array}$ \\
\hline 6 & Coumarins & $\begin{array}{l}3 \mathrm{ml} \text { of } 10 \% \mathrm{NaOH} \text { was added to } 2 \mathrm{ml} \\
\text { of aqueous extract }\end{array}$ & $\begin{array}{l}\text { Formation of yellow color } \\
\text { indicates the presence of } \\
\text { cumarins }\end{array}$ \\
\hline 7 & Emodins & $\begin{array}{l}2 \mathrm{ml} \text { of } \mathrm{NH}_{4} \mathrm{OH} \text { and } 3 \mathrm{ml} \text { Benzene was } \\
\text { added to the extract. }\end{array}$ & $\begin{array}{l}\text { Appearance of red color } \\
\text { indicates the presence of } \\
\text { emodin }\end{array}$ \\
\hline 8 & Anthocyanins & $\begin{array}{l}2 \mathrm{ml} \text { of aqueous extract is added to } 2 \mathrm{ml} \\
\text { of } 2 \mathrm{~N} \mathrm{HCl} \text { and ammonia. }\end{array}$ & $\begin{array}{l}\text { The appearance of pink-red } \\
\text { turns blue violet indicates } \\
\text { the presence of anthocyanin. }\end{array}$ \\
\hline 9 & Leucoanthocyanins & $\begin{array}{l}5 \mathrm{ml} \text { of aqueous extract added to } 5 \mathrm{ml} \text { of } \\
\text { isoamyl alcohol }\end{array}$ & $\begin{array}{l}\text { Upper layer appears red in } \\
\text { color indicates for presence of } \\
\text { leucoanthocynin. }\end{array}$ \\
\hline 10 & Steriods & $\begin{array}{l}1 \mathrm{ml} \text { of the extract was dissolved in } \\
10 \mathrm{ml} \text { of chloroform and equal volume } \\
\text { of concentrated sulphuric acid was } \\
\text { added by sides of the test tube. }\end{array}$ & $\begin{array}{l}\text { The upper layer turns red and } \\
\text { sulphuric acid layer showed } \\
\text { yellow with green } \\
\text { fluorescence indicate the } \\
\text { presence of steroids. }\end{array}$ \\
\hline 11 & Phlobatinins & $\begin{array}{l}\text { aqueous extract were boiled with } 1 \% \\
\text { aqueous } \mathrm{HCl}\end{array}$ & $\begin{array}{ll}\text { red precipitate was } \\
\text { deposition indicate } & \text { the } \\
\text { presence of phlobatinins } & \\
\end{array}$ \\
\hline
\end{tabular}

\section{ANTHELMINTIC ASSAY}

\subsection{In vivo Anthelmintic activity}

The $P$. posthuma earthworm was divided into seven groups consisting of two earthworms of equal size in each group and released into $30 \mathrm{ml}$ of the experimental formulation contained in a petri plate. The first group served as control treated with usual distilled water only, The ethanolic extract of Jasminum grandiflorum at different concentrations (5, 10 and $15 \mathrm{mg} / \mathrm{ml}$ ) constituted the second, third and fourth group and ethanolic extract of cordia dichotoma at different concentrations (5, 10 and 15 $\mathrm{mg} / \mathrm{ml}$ ) constituted the fifth, sixth and seventh group. Before initiating the experiment, all the test solutions and regular solutions were freshly prepared. The mean paralysis time was observed when no earthworm movement could be observed and the death time was documented in minutes after confirming that worms did not move when shaken or when external stimuli were given by putting the motionless worms in $50^{\circ} \mathrm{C}$ hot water ${ }^{13}$. When the worms were unable to move and the presence of a white secretion and the color of their body around 
their body diminished, the deaths of the worms were confirmed. It expressed the time for paralysis and death as minutes.

\subsection{Anthelmintic activity by Molecular Docking}

The molecular docking of compound was done into the three-dimensional X-ray structure (PDB code: 4ICU). The VLifeMDS 4.1 software was used for the docking studies. This automated method is useful for studying the binding mode of ligands binding to biomacromolecules. The three-dimension structures of ligand molecules were built, optimized (3D), and saved in PDB format using the molecular modeling program BioPredicta (VLifeMDS 4.1, pune). All nonprotein atoms were deleted, and VLifeMDSTools was used for creating 3D files from primary 2D PDB files. Hydrogen atoms were added using VLifeMDSTools (Ver. 4.1). In the present docking study, the in-silico molecular design method, implemented in the program VLifeMDS 4.1, was employed. All default docking parameters were maintained.

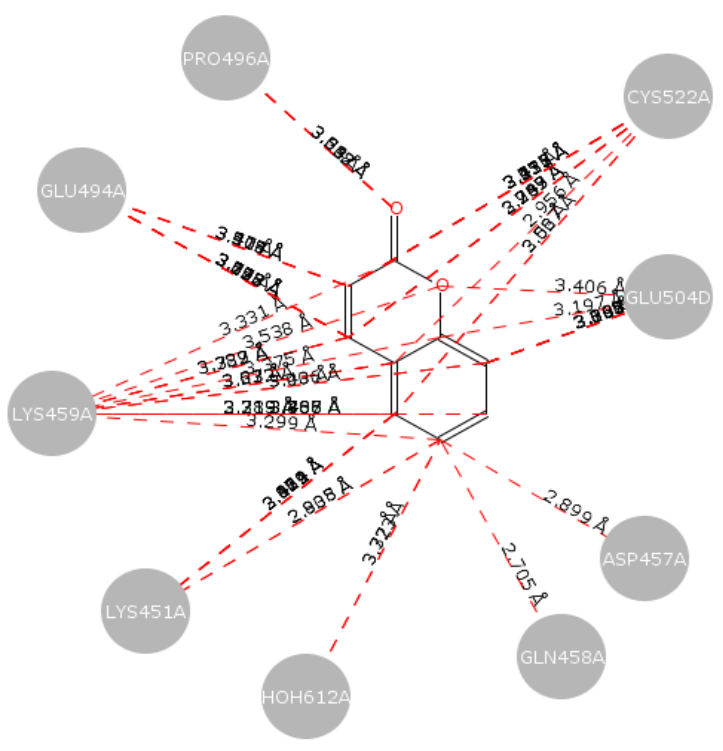

2D Image of Cumarine

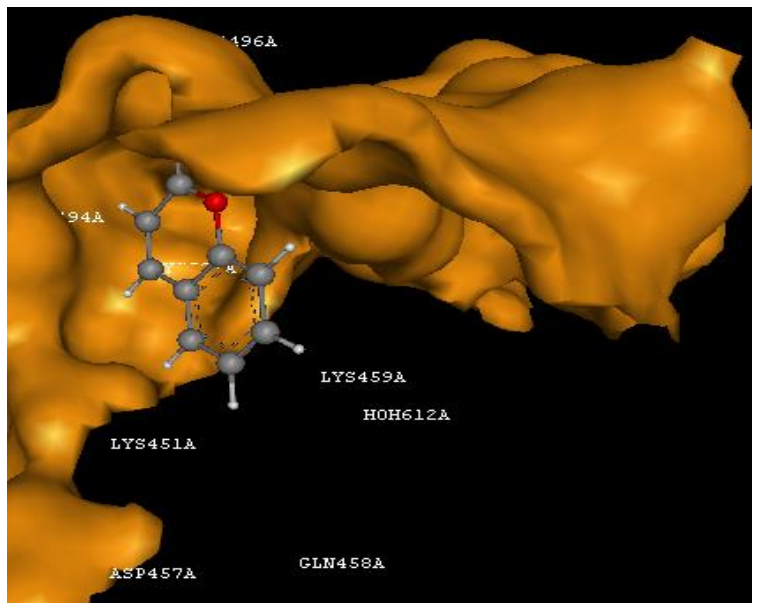

3D Image of Cumarine

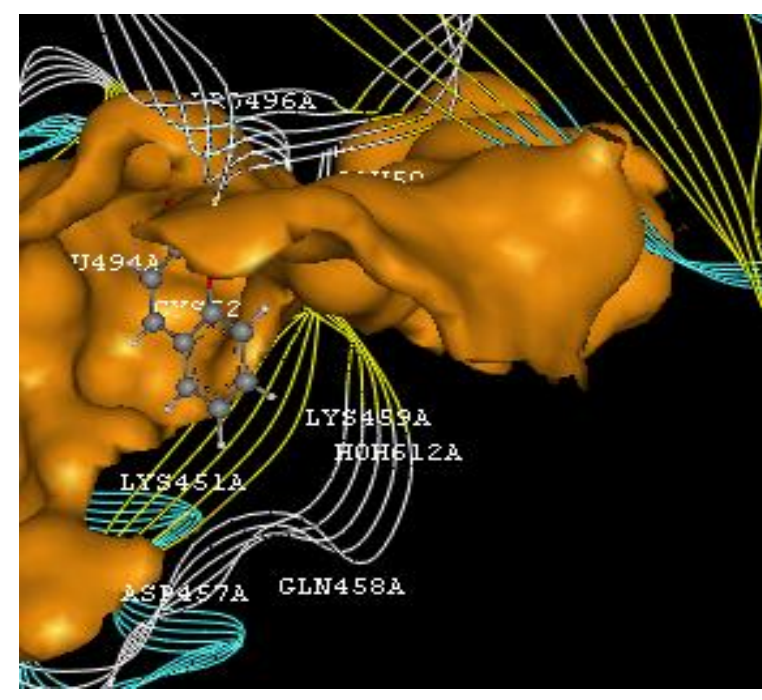

Super Impose Image of Cumarine

IV.RESULT

Table 2 : Phytochemical constituents present in extracts

\begin{tabular}{|l|l|c|c|}
\hline $\begin{array}{l}\text { Sr. } \\
\text { No. }\end{array}$ & Phytochemical & $\begin{array}{l}\text { Jasminum } \\
\text { Grandiflorum }\end{array}$ & $\begin{array}{l}\text { Cordia } \\
\text { dichotoma }\end{array}$ \\
\hline 1 & Alkaloid & + & + \\
\hline 2 & Tannis & + & - \\
\hline 3 & Anthocynin & - & - \\
\hline 4 & Flavonoids & + & + \\
\hline 5 & Terpenoid & + & + \\
\hline 6 & Coumarin & - & - \\
\hline 7 & Steroids & + & + \\
\hline 8 & Phlobatins & - & - \\
\hline
\end{tabular}


Table 3 : Anthelmintic activity

\begin{tabular}{|l|l|l|l|l|}
\hline Group & Extract & Dose $(\mathrm{mg} / \mathrm{ml})$ & Paralysis time (min) & Death time (min) \\
\hline 1 & Control & - & - & - \\
\hline 2 & Jasminum grandiflorum & $5 \mathrm{mg} / \mathrm{ml}$ & $77.01 \mathrm{~min}$ & $85.2 \mathrm{~min}$ \\
\cline { 4 - 5 } & & & $138.50 \mathrm{~min}$ & $145.5 \mathrm{~min}$ \\
\hline 3 & Jasminum grandiflorum & \multirow{2}{*}{$10 \mathrm{mg} / \mathrm{ml}$} & $71.30 \mathrm{~min}$ & $78.6 \mathrm{~min}$ \\
\cline { 4 - 5 } & & & $133.50 \mathrm{~min}$ & $139.0 \mathrm{~min}$ \\
\hline 4 & Jasminum grandiflorum & \multirow{2}{*}{$15 \mathrm{mg} / \mathrm{ml}$} & $67.37 \mathrm{~min}$ & $71.0 \mathrm{~min}$ \\
\cline { 4 - 5 } & & & $128.12 \mathrm{~min}$ & $131.5 \mathrm{~min}$ \\
\hline 5 & Cordia diachotoma & \multirow{2}{*}{$5 \mathrm{mg} / \mathrm{ml}$} & $77.06 \mathrm{~min}$ & $76.2 \mathrm{~min}$ \\
\cline { 4 - 5 } & & & $137.20 \mathrm{~min}$ & $137.6 \mathrm{~min}$ \\
\hline 6 & Cordia diachotoma & $10 \mathrm{mg} / \mathrm{ml}$ & $71.30 \mathrm{~min}$ & $73.2 \mathrm{~min}$ \\
\cline { 4 - 5 } & & & $132.20 \mathrm{~min}$ & $133.4 \mathrm{~min}$ \\
\hline 7 & Cordia diachotoma & \multirow{2}{*}{$15 \mathrm{mg} / \mathrm{ml}$} & $69 \mathrm{~min}$ & $72.5 \mathrm{~min}$ \\
\cline { 4 - 5 } & & & $129.40 \mathrm{~min}$ & $135.9 \mathrm{~min}$ \\
\hline
\end{tabular}

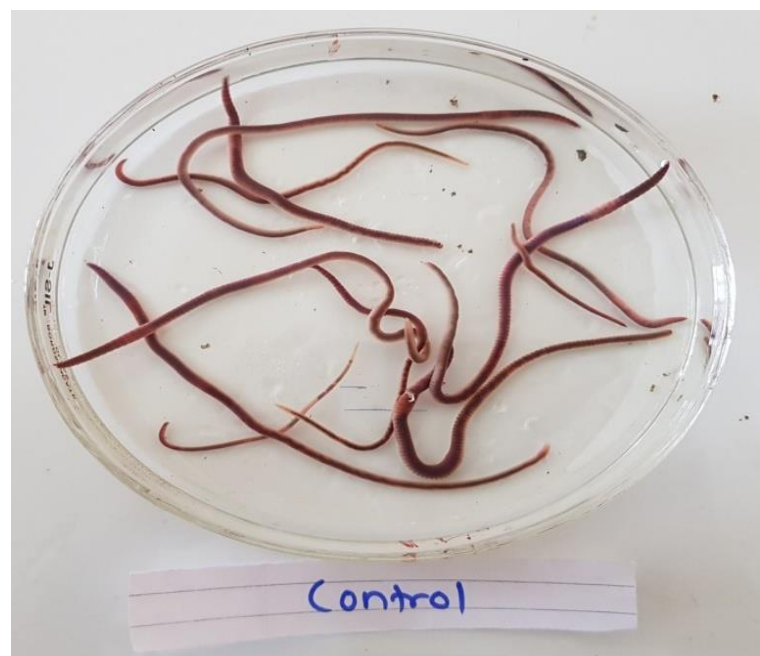

FIG 1 : CONTROL

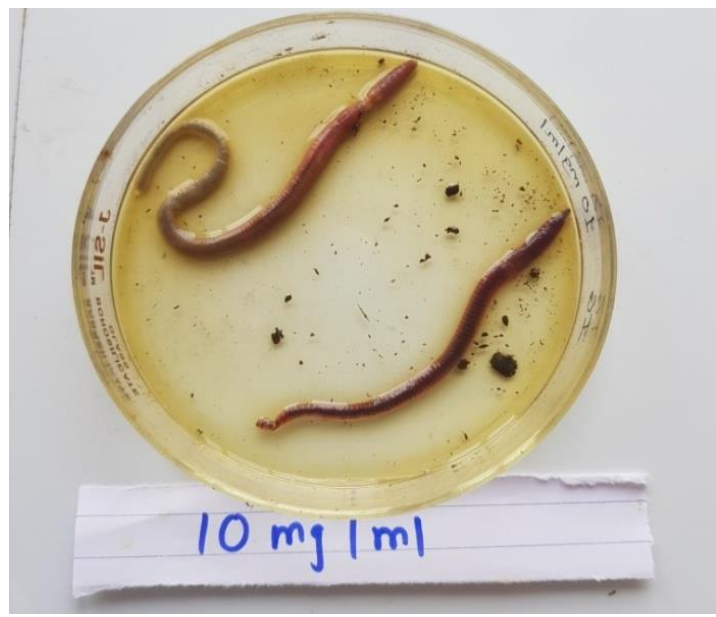

FIG 3: J. grandiflorum $(10 \mathrm{mg} / \mathrm{ml})$

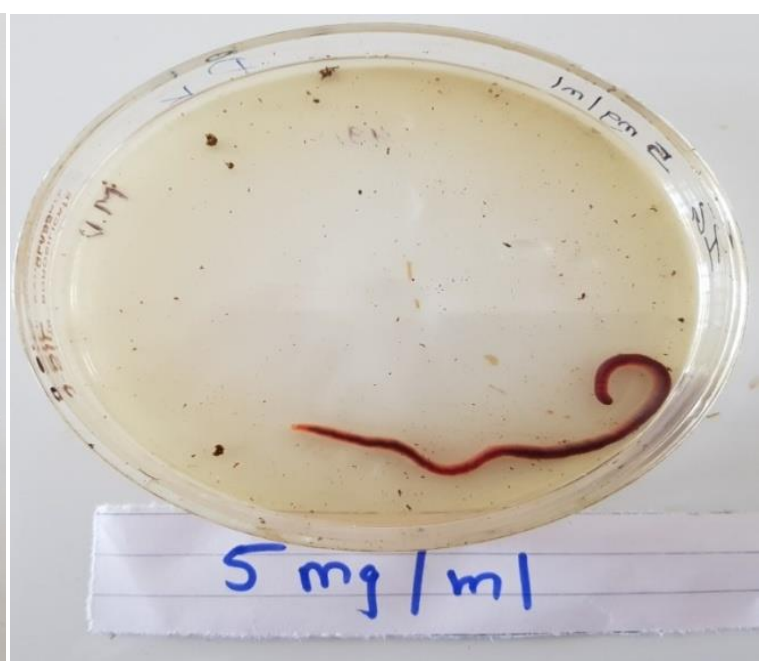

FIG 2 : J. gradiflorum $(5 \mathrm{mg} / \mathrm{ml})$

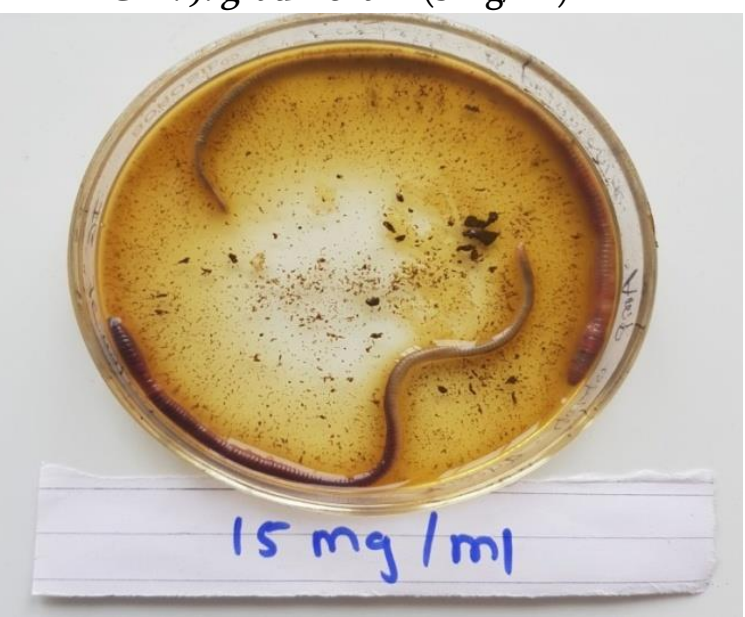

FIG 4: J. grandiflorum $(15 \mathrm{mg} / \mathrm{ml})$ 


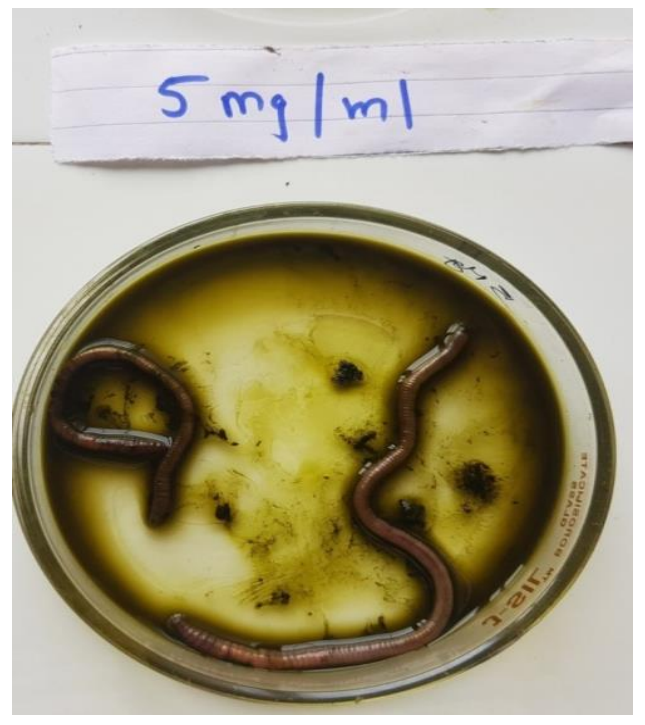

FIG 5: C. diachotoma (5mg/ml)

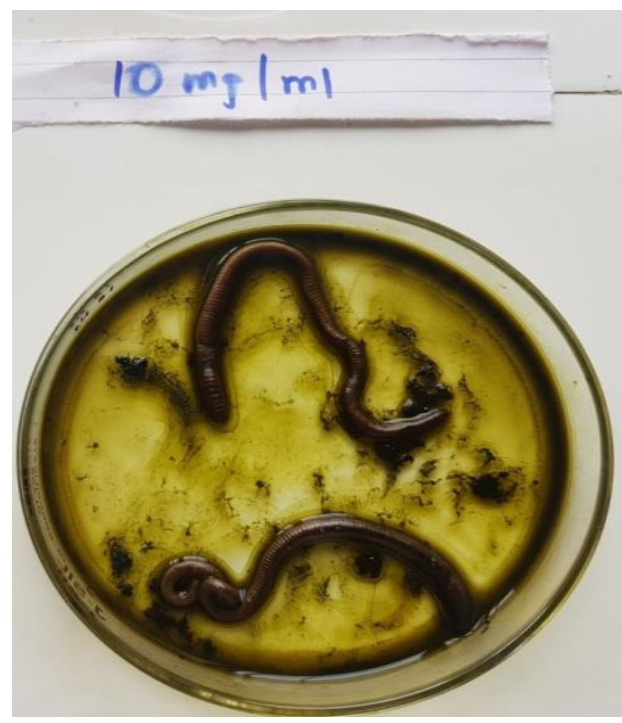

FIG 6: C. diachotoma $(10 \mathrm{mg} / \mathrm{ml})$

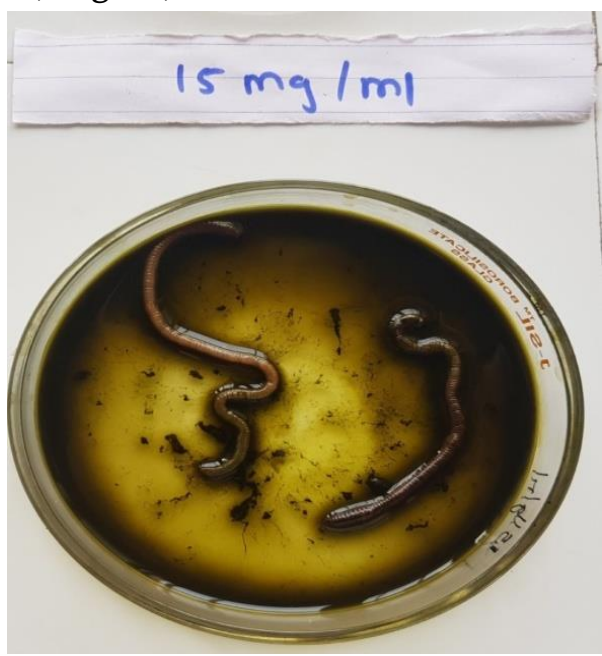

FIG 7: C. diachotoma $(15 \mathrm{mg} / \mathrm{ml})$

Preliminary phytochemical screening has shown the presence of saponin, steroid, alkaloid, tannin, flavonoid in ethanolic extract. From the above table, it is observed that Jasminum grandiflorum shown potent anthelmintic activity while Cordia diachotoma has taken long time for death of worms. Jasminum grandiflorum is showing paralysis within $7-8$ minutes while death of worms takes place 1 hour 55 minutes. Cordia diachotoma is showing paralysis within $9-10$ minutes while death of worms takes place in 2 hours 30 minutes. Future scope involves need of isolation of phytoconstituent responsible for activity

\section{DISCUSSION}

Different plants would have different chemical constitution and the composition of these chemicals may vary from one part to another part within the same plant. In order to determine the soluble phytochemical constituents, Jasminum grandiflorum and Cordia dichotoma were therefore chosen to prepare ethanolic extracts using two separate methods. The present investigation revealed the presence of phytochemicals in ethanolic solvent extracts of Jasminum grandiflorum and Cordia diachotoma leaf, such as alkaloids, glycoside, coumarin, saponins, flavonoids and tannins. In Jasminum grandiflorum ethanolic extract, more phytochemicals and the 
highest extractive percentage (11.6 percent) were found and showed the highest anthelmintic activity. Phytochemicals, also known as secondary metabolites, are found in complex mixtures that vary by plant organ and growth stage ${ }^{14}$. Knowing the phytochemical constituents of Jasminum grandiflorum and Cordia dichotoma leaves will help you get the most out of this plant in terms of medicine. Vital sources of antiviral, antitumor and antimicrobial agents have been identified as phytochemicals contained in plants and are therefore used as constituents in allopathic medicine ${ }^{15}$ and in other medical systems as well. In the current study, anthelmintic activity of ethanolic leaf extracts of Jasminum grandiflorum and Cordia dichotoma was tested against $P$. posthuma which resembles intestinal worms in their reaction to anthelmintic agents and are easily available. The Cordia dichotoma ethanolic extract exhibited poor anthelmintic activity when compared to Jasminum grandiflorum ethanolic extract and the standard drug albendazole (BENDEX Suspension). The highest anthelmintic activity can be responsible for the occurrence of alkaloids and tannins in ethanolic extract. As the concentrations increased, the anthelmintic activity of ethanolic extracts increased. Bendgude et al. ${ }^{16}$ also reported that the standard reference drug, albendazole, ethanolic extracts greatly decreased the paralysis and death time of worms in a dose-dependent way. Phytochemicals like alkaloids, phenols, etc. shows important anthelmintic activity ${ }^{17}$ has been reported to function on the central nervous system and cause earthworm paralysis. Tannins have been reported to interfere with worm power generation by uncoupling oxidative phosphorylation or binding to the gastrointestinal tract's free protein and leading to worm death ${ }^{18}$. Together or separately, phytochemicals can work by inhibiting tubulin polymerization and blocking glucose uptake ${ }^{19}$ and damaging the mucopolysaccharide membrane of worms, exposing the outer layer and restricting their earthworm movement, which can eventually cause paralysis and ultimately death ${ }^{20}$.

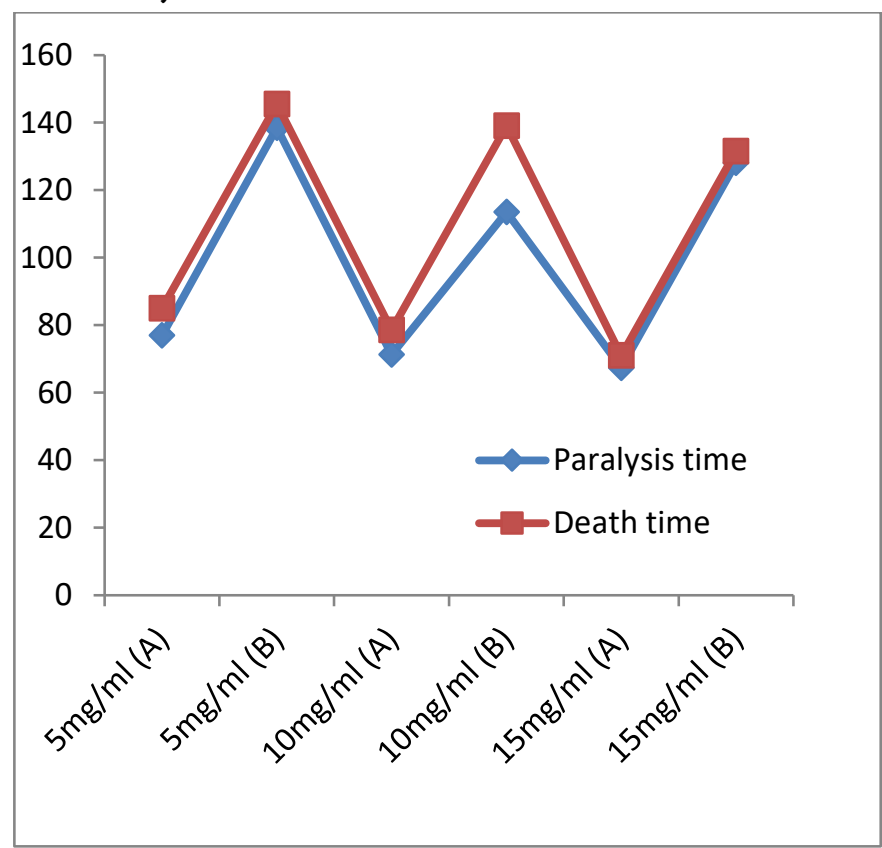

Graph 1: Jasminum grandiflorum

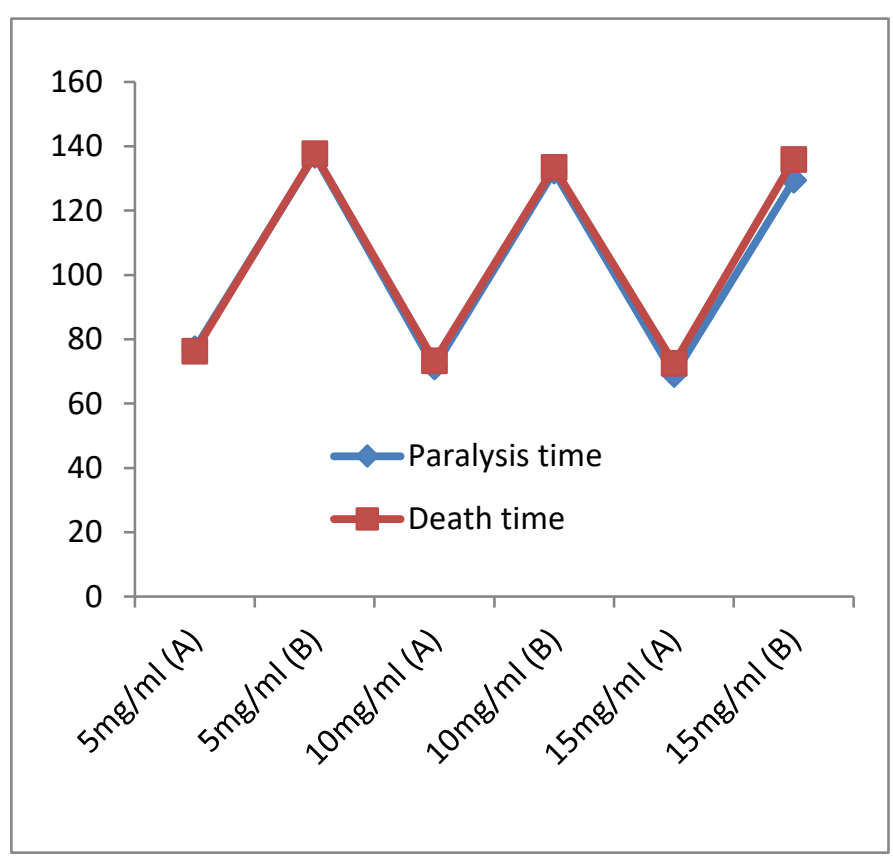

Graph 2: Cardia diachotoma

\section{CONCLUSION}

By performing extraction of Jasminum grandiflorum and Cordia diachotoma it was found that both extract contain cumarine as active constituent for anthelmintic activity. It was concluded that Jasminum grandiflorum shows more activity than 
Cordia diachotoma. Further work will emphasize the isolation and characterization of active principles responsible for anthelmintic activity of leaf extracts of Jasminum grandiflorum and Cordia diachotoma.

\section{VII.REFERENCES}

[1]. Chandran RP, Ahlen IB, Reshma S, Vineetha J, Neeraja U, Aswathy S., Analysis of phytochemical, antimicrobial and disinfectant properties of leaf extracts H. suaveolens (L.), Poit. J Chem Pharm Res. 2016;8: 746-752.

[2]. Babu PD, Subhasree RS., Antimicrobial activities of Lawsonia inermis: A review, Acad J Plant Sci. 2009;2: 231-32.

[3]. Aaer M, Man I, Mohamed AO, Moustafa FM., Cytotoxic effects of albendazole, antiparasitic drug, on the liver of the rat: Subchronic study, Egypt J Biol. 1999;1:16-29.

[4]. Aswar M, Aswar U, Watkar B, Vyas M, Wagh A, Gujar KN, Anthelmintic activity of Ficus benghalensi, Int J Green Pharm. 2008;2:170-172

[5]. Parakh S, Parakh PM. Jasminum grandiflorum Linn.(Chameli) : Ethanobotany, Phytochemistry and Pharmacology - A review. Pharmacologyonline 2009; 2: 586-595

[6]. Maisale AB, Attimarad SL, Haradagatti DS, Karigar A. Anthelmintic activity of fruit of Cordia Dichotoma. IJRAP 2010; 1(2): 597- 600

[7]. Feroz MR, Ahmad STAK, Sindhu, Shahbaz AM. Antifungal activities of saponins from indigenous plant roots. Pak. Vet. J. 1993;13:4.

[8]. Kokate CK, Purohit AP, Gokhale SB. Practical Pharmacognosy,.Vallabh Prakashan, New Delhi. 2004;2:466-470.

[9]. Patil KJ, Patil VA, Patil SV, Bhutkar AS. Comparative preliminary phytochemical studies of Jasminum multiflorum and Jasminum officinale, ISSN 2012;1:2319-5037.

[10]. Santhi R., Lakshmi G., Priyadharshini A.M. and Anandaraj L., Phytochemical screening of Nerium oleander leaves and Momardica charantia leaves, Int.Res.J. Pharmacy.2011; 2(1):131-135.

[11]. Savithramma N., Rao Linga M. and Suhrulatha $\mathrm{D}$, Screening of medicinal plants for secondary metabolites, Middle East J. Scientific Res.2011; 8(3): 579-584.

[12]. Vaghasiya Y., Dave R. and Chanda S., Phytochemical analysis of some medicinal plants from western region of India, Res. J. Medicinal Plants. 2011; 5(5): 567-576.

[13]. Dey P, Debnath P, Bhakta T., Evaluation of anthelmintic activity of Molineria recurvata leaf extracts, Int Res J Pharm Appl Sci. 2012;2:16-20.

[14]. Banerji A, Chadha MS, Malshet VG. Isolation of 5hydroxy-36- 73'4'-pentamethoxy flavone from Vitex negundo. J Phytochem. 1969;8:511-512.

[15]. Nair R, Kalariya T, Chanda S. Antibacterial activity of some selected Indian medicinal flora. Turkish J Biol. 2005;29:41-47

[16]. Bendgude RD, Maniyar MG, Kondawar MS, Patil SB, Hirave RV. Anthelmintic activity of leaves of Mimosa pudica. ,Int J Ins pharma life Sci. 2012; 2:120-123.

[17]. Bate - Smith EC., The phenolic constituent of plants and their taxonomic significance, dicotylendons, J Linn Soc Bot., 1962; 58:95-103.

[18]. Jain D, Maheshwari D, Somani R., Anthelmintic potential of herbal drugs. J Adv Drug Res. 2011; 1: 965-967.

[19]. Roy H, Chakraborty A, Bhanja S, Nayak BS, Mishra SR, Ellaiah P., Preliminary phytochemical investigation and anthelmintic activity of Acanthospermum hispidum. J Pharm Sci Technol. 2010; 2:217-221.

[20]. Chandrasekhar CH, Latha KP, Vagdevi HM, Vaidya VP., Anthelmintic activity of the crude extracts of Ficus racemosa. Int J Green Pharm. 2008; 1:100-103.

[21]. Kaur S, Kumar B, Puri S, Tiwari P, Divakar K., Comparative study of anthelmintic activity of 
aqueous and ethanolic extract of bark of Holoptelea integrifolia. IDDR; 2010:

[22]. Kane SR, Mohite SK, Shete JS. Antihelmintic activity of aqueous and methanolic extracts of Euphorbia thymifolia Linn. In J Pharm Tech Res 2009; 1:666-9.

[23]. Ganesh H Wadkar, Sandeep R Kan, Sunil S. Matapati, Mahesh G. Hogade, In-vitro anthelmintic activity of Caesalpinia bonducella (Linn). Flem. leaves.. Journal of Pharmacy Research Vol.3.Issue 5.May 2010.

[24]. Hasan R Seresht, Hamid Cheshomi, Farhanz Falanji, Fatemeh M. Mohtlag, Maryam Hashemian, Erfan Mireskandari, Cytotoxic activity of caffeic acid and gallic acid against MCF-7 human breast cancer cells: An in silico and in vitro study. Avicenna J Phytomed. 2019; 9(6): 574-586.

[25]. Raut I.D., Dhadde G.S., Yadav J.P., Sapate R.B., Mali H.S., In Vitro Anthelmintic Activity of Crude Extract of Flowers of Bougainvillea Spectabilis Wild Against Pheretima Posthuma, International Journal of Pharmacy and Pharmaceutical Research, 2020: 17; 1-18.

\section{Cite this article as :}

Muskan M. Bhaldar, Sandeep R. Kane, Hanmant S. Mali, Hemant S. Kandle, "A Comparative Anthelmentic Studies on Jasminum Grandiflorum and Cordia Diachotoma", International Journal of Scientific Research in Science and Technology (IJSRST), Online ISSN : 2395-602X, Print ISSN : 23956011, Volume 8 Issue 4, pp. 637-645, July-August 2021. Available at

doi : https://doi.org/10.32628/IJSRST218499

Journal URL : https://ijsrst.com/IJSRST218499 